\title{
Ograniczenia ustawodawcy w kształtowaniu zadań gminy
}

\author{
Orzeczenie Trybunału Konstytucyjnego z dnia 25 października 1995 r., K 4/95'
}

1. Przekazywanie zadań publicznych do realizacji samorządowi terytorialnemu należy do ustawodawcy, który może to uczynić jedynie ustawą. Ustawodawca posiada w powyższym zakresie swobodę co do podziału zadań publicznych pomiędzy administrację rządową i administrację samorządową. Ustawodawca, dokonując kwalifikacji i przekazania zadań, jak się wydaje, kieruje się kryterium przedmiotowym i podmiotowym, co skutkuje dość istotnym ograniczeniem swobody w ich przekazywaniu.

2. Sposób realizacji zadań ( $w$ omawianym przypadku zaspokojenie potrzeb mieszkaniowych mieszkańców) przez samorząd gminny może przybrać różne formy. Gmina może bezpośrednio realizować przekazane zadanie, jak również poprzez realizację zadań detalizujących (pośrednio przyczyniających się do realizacji wyżej wymienionego zadania). Realizacja zadań detalizujących będzie prowadzić do pełnej realizacji konkretnego zadania własnego gminy, jeśli doprowadzi do zaspokojenia potrzeb mieszkańców, tj. potrzeb mieszkaniowych.

3. Finansowe zabezpieczenie realizacji zadań przez samorząd gminny należy, co do zasady, do gminy, która musi zabezpieczyć we własnym budżecie środki na realizację konkretnego zadania. Jednakże ustawodawca, przekazując gminie do realizacji nowe zadanie, winien zapewnić i przekazać środki finansowe w wysokości wystarczającej do jego realizacji, tj. na dotychczasowym poziomie.

\author{
Paweł Sosnowski \\ Prokuratoria Generalna Rzeczypospolitej Polskiej \\ p.sosnowski@ans.pw.edu.pl \\ ORCID 0000-0002-0419-2981
}

https://doi.org/10.26881/gsp.2020.1.09

1 OTK ZU 1995, nr 2, poz. 11. Wyżej wymienione orzeczenie Trybunału Konstytucyjnego było już przedmiotem glos zob.: E. Tegler, Glosa do orzeczenia TK z dnia 23 października 1995 r., K 4/95, ST 1996, nr 7-8, s. 152-162; A. Agopszowicz, Glosa do orzeczenia TK z dnia 23 października 1995 r., K 4/95, ST 1996, nr 7-8, s. 162-164; A. Borodo, Glosa do orzeczenia TK z dnia 23 października 1995 r., K 4/95, ST 1996, nr 10, s. 60-65; K. Podgórski, S. Nitecki, Glosa do orzeczenia TK z dnia 23 października 1995 r., K 4/95, ST 1996, nr 10, s. 65-69; N. Gajl, Glosa do orzeczenia TK z dnia 23 października 1995 r., K 4/95, ST 1996, nr 10, s. 69-80. 


\section{Glosa}

\section{Wprowadzenie}

Glosowane orzeczenie zostało wydane przez Trybunał Konstytucyjny (dalej: TK lub Trybunał) w związku z wnioskiem Związku Miast Polskich, Rady Miasta w Skierniewicach, Rady Miasta w Elblągu, Rady Miasta w Chełmku, Sejmiku Województwa Poznańskiego, Sejmiku Województwa Opolskiego o stwierdzenie zgodności ustawy z dnia 2 lipca 1994 r. o najmie lokali mieszkalnych i dodatkach mieszkaniowych (Dz. U. Nr 105, poz. 509, ze zm.) (dalej: u.n.l. $)^{2}$ w zakresie art. 4, art. 39 ust. 2, art. 45 i art. 68 oraz rozporządzenia Rady Ministrów z dnia 7 listopada 1994 r. w sprawie dotacji dla gmin na dofinansowanie wypłat dodatków mieszkaniowych (Dz. U. Nr 119, poz. 571, ze zm.) z ustawą konstytucyjną z dnia 17 października 1992 r. o wzajemnych stosunkach między władzą ustawodawczą i wykonawczą RP oraz o samorządzie terytorialnym (Dz. U. Nr 84, poz. 426, ze zm.) (dalej: Mała Konstytucja lub Konstytucja), Europejską Kartą Samorządu Terytorialnego sporządzoną dnia 15 października 1985 r. i ratyfikowaną w imieniu Rzeczypospolitej Polskiej dnia 26 kwietnia 1994 r. (Dz. U. Nr 124, poz. 607) (dalej: Karta lub EKST) w zakresie art. 5, art. 7 i art. 9 ust. 1 oraz z ustawami, tj. ustawą z dnia 8 marca 1990 r. o samorządzie terytorialnym (Dz. U. Nr 16, poz. 95, ze zm.) (dalej u.s.t.) ${ }^{3}$, ustawą z dnia 10 grudnia 1993 r. o finansowaniu gmin (Dz. U. Nr 129, poz. 600, ze zm.)4, ustawą z dnia 5 stycznia 1991 r. - Prawo budżetowe (Dz. U. z 1993 r. Nr 72, poz. 344, ze zm.).

Glosujący wskazuje, że wyżej wymienione orzeczenie TK zostało wydane w czasie obowiązywania ustawy konstytucyjnej z dnia 17 października 1992 r. o wzajemnych stosunkach między władzą ustawodawczą i wykonawczą RP oraz o samorządzie terytorialnym oraz ustawy o najmie lokali mieszkalnych i dodatkach mieszkaniowych które to akty już nie obowiązują.

Trybunał Konstytucyjny orzekł o niekonstytucyjności jedynie art. 45 ust. 3 u.n.l., odnosząc go do wzorca konstytucyjnego wynikającego z Małej Konstytucji - co może oznaczać, że postawione w nim tezy nie są już aktualne. Obecnie mamy odpowiednie normy prawne zawarte w innych aktach prawnych, tj. w Konstytucji Rzeczypospolitej

\footnotetext{
2 Ustawa utraciła moc z dniem 10 lipca 2001 r., z wyjątkiem przepisów rozdziału 6, zgodnie z art. 39 ust. 1 ustawy z dnia 21 czerwca 2001 r. o ochronie praw lokatorów, mieszkaniowym zasobie gminy i o zmianie Kodeksu cywilnego (tekst jedn.: Dz. U. z 2019 r., poz. 1182). Ponadto wskazuje się, że z dniem 1 stycznia 2002 r. weszła w życie ustawa z dnia 21 czerwca 2001 r. o dodatkach mieszkaniowych (tekst jedn.: Dz. U. z 2019 r., poz. 2133).

3 Obecny tytuł ustawy: „o samorządzie gminnym".

4 Ustawa utraciła moc z dniem 1 stycznia 1999 r., na podstawie art. 65 ustawy z dnia 26 listopada 1998 r. o dochodach jednostek samorządu terytorialnego w latach 1999 i 2000 (Dz. U. Nr 150, poz. 983), jednakże przepisy art. 3 pkt 3-6, art. 4 pkt 1 lit. a)-e), pkt 2 lit. a) i b) i pkt 3, art. 14 ust. 3, art. 27 ust. 2 i art. 27 a ust. 1 i 2 zachowały moc do dnia 31 grudnia 1999 r. i miały zastosowanie do obliczania zapotrzebowania na dotację udzielaną gminom na dofinansowanie wypłat dodatków mieszkaniowych w 1999 r., zgodnie z art. 45b u.n.I. (Dz. U. z 1998 r. Nr 120, poz. 787).

5 Ustawa uchylona z dniem 1 stycznia $1999 \mathrm{r}$.
} 
Polskiej z dnia 2 kwietnia 1997 r. (Dz. U. Nr 78, poz. 483, ze zm.) (dalej: Konstytucja RP), ustawie z dnia 21 czerwca 2001 r. o ochronie praw lokatorów, mieszkaniowym zasobie gminy i o zmianie Kodeksu cywilnego (tekst jedn.: Dz. U. z 2019 r., poz. 1182), a także w ustawie z dnia 21 czerwca 2001 r. o dodatkach mieszkaniowych (tekst jedn.: Dz. U. z 2019 r., poz. 2133), przez co problematyka określenia charakteru zadań publicznych wciąż jest aktualna.

Mała Konstytucja regulowała kwestie organizacji, zadań oraz finansowania samorządu terytorialnego. Podstawową formą organizacji lokalnego życia publicznego był samorząd terytorialny, a na podstawową jednostkę tego samorządu kreowana była gmina (art. 70 ust. 1 i 4). Samorząd terytorialny wykonuje istotną część zadań publicznych w imieniu własnym i na własną odpowiedzialność dla zaspokojenia potrzeb mieszkańców, z wyłączeniem zadań zastrzeżonych ustawowo do kompetencji administracji rządowej. Ustawodawca konstytucyjny wyraźnie zastrzegł obowiązek wyposażenia samorządu terytorialnego w „odpowiednie środki finansowe” (art. 71 ust. 1-3). Jednocześnie wskazane zostały dochody samorządu terytorialnego, na które składały się: dochody własne, subwencje i dotacje. W zakresie zadań publicznych źródła dochodów miały być gwarantowane ustawowo (art. 73).

Obecnie obowiązująca Konstytucji RP również zawiera w rozdziale VII normy prawne dotyczące samorządu terytorialnego w zakresie organizacji, zadań i dochodów samorządu terytorialnego. Samorząd terytorialny wykonuje zadania publiczne służące zaspokajaniu potrzeb wspólnoty samorządowej jako zadania własne (art. 166) z zastrzeżeniem, że nie są one przekazane przez Konstytucję RP lub ustawy dla organów innych władz publicznych (art. 163). Ustawodawca jednoznacznie wskazał, iż udział jednostek samorządu terytorialnego (dalej: j.s.t.) w dochodach publicznych musi odpowiadać realizowanym przez nie zadaniom, a jako źródła dochodów wskazano: dochody własne, subwencje ogólne i dotacje celowe z budżetu państwa (art. 167 ust. 1 i 2). Na dochody składają się także podatki i opłaty lokalne. Ponadto ustawodawca konstytucyjny zabezpieczył samorząd terytorialny przed zmianami realizowanych zadań. Zmiany zakresu zadań j.s.t. powiązane zostały ze zmianami w podziale dochodów publicznych (art. 167 ust. 4). Nadal podstawową jednostką samorządu terytorialnego jest gmina (art. 164 ust. 1).

Kwestionowana ustawa o najmie lokali mieszkalnych i dodatkach mieszkaniowych wyraźnie stanowiła, że do zadań własnych gminy zalicza się zaspokajanie potrzeb mieszkaniowych członków wspólnoty samorządowej (art. 4) oraz wypłatę dodatków mieszkaniowych (art. 45 ust. 1).W przypadku drugiego ze wskazanych zadań własnych gmina uzyskuje dotację celową na jego realizację z budżetu państwa, w granicach kwot określonych na ten cel w ustawie budżetowej (art. 45 ust. 2). Kompetencje do określenia zasad i trybu ustalania oraz przekazywania gminom z budżetu państwa dotacji oraz szczegółowych zasad przyznawania dodatków mieszkaniowych i ich wypłaty przyznane zostały Radzie Ministrów. Powyższe zasady i procedury Rada Ministrów określała w formie rozporządzenia (art. 45 ust. 3). Ustawa jednocześnie wskazywała podmioty, którym przysługiwał dodatek mieszkaniowy (art. 39). 
Powyższa ustawa zastąpiona została przez dwa akty prawne, tj. ustawę o ochronie praw lokatorów, mieszkaniowym zasobie gminy i o zmianie Kodeksu cywilnego oraz ustawę o dodatkach mieszkaniowych.

Ustawa o ochronie praw lokatorów, mieszkaniowym zasobie gminy i o zmianie Kodeksu cywilnego do zadań własnych gminy zalicza tworzenie warunków do zaspokajania potrzeb mieszkaniowych wspólnoty samorządowej i ma zapewnić lokale w ramach najmu socjalnego i lokale zamienne, a także zaspokaja potrzeby mieszkaniowe gospodarstw domowych o niskich dochodach (art. 4 ust. 1 i 2). Realizacja powyższych zadań ma być realizowana przy wykorzystaniu mieszkaniowego zasobu gminy lub w inny sposób (art. 4 ust. 3 w zw. z art. 20 ust. 1). Na realizację powyższych zadań gminy mogą otrzymywać dotacje celowe z budżetu państwa (art. 4 ust. 4). Ponadto obowiązkiem gminy jest wskazanie pomieszczenia tymczasowego w przypadku wykonywania przez komornika obowiązku opróżnienia lokalu (art. 4 ust. 2a).

Natomiast ustawa o dodatkach mieszkaniowych w art. 9a jako zadanie własne gminy wskazuje wypłatę dodatków mieszkaniowych.

Aktualność wyroku zawiera się w aktualności problematyki i ciągłości zadań związanych z obowiązkiem realizacji zabezpieczenia tzw. potrzeb mieszkaniowych. W pozostałym zakresie TK stwierdził zgodność regulacji ustawowej z Małą Konstytucją, jednakże postawił dyskusyjne tezy dotyczące:

1. pełnej swobody ustawodawcy w przekazywaniu zadań samorządowi gminnemu;

2. sposobu realizacji zadań własnych przez samorząd terytorialny, tj. poprzez realizację zadań detalizujących;

3. braku zapewnienia pełnego finansowania (adekwatności) realizacji zadań przekazanych gminie ${ }^{6}$.

\section{Przekazywanie przez ustawodawcę zadań samorządowi gminnemu}

Trybunał Konstytucyjny konstatuje, że ustrojodawca w przepisach Małej Konstytucji, w szczególności w art. 71 ust. 1, pozostawia ustawodawcy „zwykłemu” szeroką swobodę powierzania zadań publicznych samorządowi terytorialnemu, jak również klasyfikowania tych zadań. W przepisach Małej Konstytucji nie ustalono materialnego, wiążącego ustawodawcę kryterium rozdzielenia zadań publicznych pomiędzy administrację rządową i samorząd terytorialny ani też kryterium, jakim ustawodawca obowiązany byłby się kierować, określając pewne zadania publiczne powierzone samorządowi terytorialnemu jako zadania własne tego samorządu. Z powołanych przepisów Małej Konstytucji w drodze interpretacji można tylko wyprowadzić nader ogólną dyrektywę dla ustawodawcy, aby powierzał samorządowi terytorialnemu jako własne takie zadania, które, po pierwsze, mają charakter publiczny, po drugie, wiążą się z zaspokojeniem potrzeb mieszkańców, tj. osób mieszkających w gminie, i po

6 O zasadzie adekwatności zob. E. Kornberger-Sokołowska, Realizacja zasady adekwatności w procesach decentralizacji finansów, ST 2001, nr 3, s. 13 i nn. 
trzecie, mogą być realizowane w obrębie właściwości miejscowej jednostki samorządu terytorialnego. Wypłata dodatków mieszkaniowych spełnia wszystkie te warunki: ma charakter publiczny, wiąże się z zaspokojeniem potrzeb mieszkańców gminy i może być skutecznie dokonywana w granicach gminy.

Natomiast Trybunał Konstytucyjny nie dostrzegł w przepisach Małej Konstytucji obowiązkowego warunku uzależniającego powierzenie samorządowi terytorialnemu danego zadania wyłącznie od lokalnego wymiaru tego zadania w takim znaczeniu, by musiało ono mieć na celu rozwiązywanie problemów występujących tylko w skali lokalnej, tzn. w ramach poszczególnych jednostek samorządu terytorialnego. Powszechnie bowiem wiadomo, że problemy ogólne, występujące w skali kraju podlegają konkretyzacji (detalizacji) w poszczególnych gminach oraz są rozwiązywane w skali ogólnej poprzez ich podjęcie i rozwiązywanie w skali lokalnej, co z woli ustawodawcy może, a niekiedy i powinno zostać zaliczone do zadań własnych gmin.

Zadanie własne gminy polegające na wypłacie dodatków mieszkaniowych przewidziane $w$ art. 45 ust. 1 u.n.l. stanowi jedną z kompetencji organów gminy konkretyzujących zadanie własne (funkcję) gminy określone w art. 4 u.n.l. jako zaspokajanie potrzeb mieszkaniowych członków wspólnoty samorządowej. Wykonywanie ustawowo przyznanych kompetencji jest nie tylko uprawnieniem, ale i obowiązkiem każdego podmiotu władzy publicznej. Dlatego mimo braku w ustawie przepisu nazywającego expressis verbis to zadanie gminy obowiązkowym jest ono - jako ustawowa kompetencja gminy - ze swojej istoty i charakteru właśnie obowiązkowym i gmina, będąc jedynym podmiotem ustawowo zobowiązanym do wypłaty osobom uprawnionym dodatków mieszkaniowych, nie może uchylić się od jego realizacji. Pozostawienie gminie $w$ tym zakresie dowolności prowadziłoby do niemożliwej do zaakceptowania w państwie prawnym sytuacji, w której roszczenia obywateli, uzyskane na podstawie ustawy, do dodatków mieszkaniowych byłyby zaspokajane w zależności od decyzji poszczególnych gmin albo nie byłyby zaspokajane w ogóle.

Artykuł 6 u.s.t. wskazuje, że jest to zadanie własne gminy. Jednocześnie warto zaznaczyć, co zresztą podkreśla się w literaturze, że to samo zadanie (cel społeczny) realizowane jest, na ogół, przez kilka organów, a dopiero określone w ustawach kompetencje pozwalają na ustalenie, co należy do jakiego organu. Zatem przypisanie gminom jako zadania własnego zaspokajania potrzeb mieszkaniowych członków wspólnoty pozwala zaliczyć gminy do podmiotów, którym ustawodawca powierzył realizację konstytucyjnego obowiązku poprawy sytuacji mieszkaniowej, spoczywającego na Rzeczypospolitej Polskiej.

Trybunał Konstytucyjny wskazał, że kwalifikacja przypisanego gminie zadania jako własnego zależy, z woli ustrojodawcy, od rozstrzygnięcia ustawowego: zadania własne gmina wykonuje przecież "w ramach ustaw" (art. 71 ust. 1 Małej Konstytucji), zadania "zlecone" ze sfery administracji rządowej - „w zakresie uregulowanym ustawami" (art. 71 ust. 3 Małej Konstytucji), natomiast nie wykonuje w ogóle „zadań zastrzeżonych ustawowo do kompetencji administracji rządowej" (art. 71 ust. 1 Małej Konstytucji). Z powyższego wynika bezspornie, że ustawodawca "zwykły” dysponuje szeroką swobodą regulowania zakresu zadań publicznych samorządu terytorialnego oraz 
kwalifikowania ich jako własnych bądź zleconych, bacząc, aby stanowiły „istotną część” zadań publicznych w ogólności, tzn. realizowanych przez ogół władz publicznych.

Dodatkowo Trybunał wskazał, że pozostawiona przez ustawodawcę konstytucyjnego ustawodawcy zwykłemu swoboda w dokonywaniu kwalifikacji zadań samorządu terytorialnego jako własnych lub jako zleconych jest nadmierna. Konstytucyjna pozycja ustrojowa samorządu terytorialnego uzasadnia określenie w samej konstytucji (Małej Konstytucji) materialnych kryteriów takiego podziału, wiążących ustawodawcę „zwykłego".

Według glosującego należy postawić pytanie - Czy istnieje konstytucyjny wzorzec podziału zadań pomiędzy podmioty administracji publicznej?

Jak się wydaje, ustawodawca w Małej Konstytucji oraz w Konstytucji RP wyraźnie wskazał kryteria podziału zadań publicznych na zadania samorządowe i rządowe. Pierwsze kryterium to kryterium przedmiotowe zaspokajania potrzeb - zadania, przedmiotem których jest „zaspokajanie potrzeb wspólnoty samorządowej”, to zadania samorządowe, natomiast zadania, przedmiotem których jest „zaspokajanie potrzeb wspólnoty krajowej", to zadania administracji rządowej. Drugie kryterium to kryterium podmiotowe, tzn. określające, do kompetencji którego podmiotu zastrzeżone zostało realizowanie konkretnego zadania. Zadania zastrzeżone do realizacji przez organy samorządu terytorialnego stanowią zadania samorządowe, a zastrzeżone do realizacji przez organy administracji rządowej to zadania rządowe (np. zadania z zakresu bezpieczeństwa zewnętrznego, polityka zagraniczna). Ustawodawca w Konstytucji RP wyraźnie wskazał, że gmina realizuje wszystkie zadania niezastrzeżone na rzecz innych jednostek samorządu terytorialnego.

Realizacja konkretnego zadania przez samorząd terytorialny ma służyć także sprawniejszemu, skuteczniejszemu oraz jakościowo lepszemu jego wykonaniu, niż gdyby było ono realizowane przez administrację rządową.

Mając na uwadze powyższe, należy wskazać, że zakres zadań samorządu gminnego może być rozszerzany przez ustawodawcę zwykłego, jednakże nie może on czynić tego według swobodnego uznania (dowolnie go kształtować). Posiada on wprawdzie swobodę w kształtowaniu zadań gminy, ale musi kierować się kryteriami ich podziału, tj. kryterium przedmiotowym i kryterium podmiotowym. W przeciwnym razie działanie takie prowadziłoby do sytuacji, w której samorząd terytorialny mógłby być obciążany zadaniami, których nie byłby w stanie sprawnie realizować, a w skrajnych przypadkach nie mógłby ich w ogóle realizować.

Ponadto przyjęcie, że ustawodawca posiada nieograniczoną (pełną) swobodę przy rozstrzyganiu, jakie zadania ma realizować gmina (samorząd terytorialny), a jakie administracja rządowa, a szerzej o charakterze zadań przekazywanych samorządowi terytorialnemu (bez zastosowania wyżej wymienionych kryteriów podziału), może prowadzić do zatarcia znaczenia podziału zadań na własne i zlecone. Może także prowadzić do naruszenia reguł dochodów służących finansowaniu zadań własnych oraz zadań zleconych?

\footnotetext{
7 Por. wyrok TK z dnia 13 grudnia 2018 r., K 34/16, IPO TK [dostęp: 13.12.2019].
} 
Przyjmując, że ustawodawca uwzględnia wyżej wymienione kryteria przy podziale zadań, można zaakceptować kompetencje ustawodawcy do regulowania zakresu zadań j.s.t. w drodze ustaw. Może tego dokonać albo poprzez przypisanie zadania gminie poprzez rozszerzenie katalogu zadań gminy w ustawie ustrojowej, albo poprzez przypisanie w ustawie prawa materialnego. Trudno sobie wyobrazić sytuację, że ustawodawca rozszerzy zakres zadań j.s.t., w tym gmin, poprzez wprowadzenie konkretnego zadania do Konstytucji RP - zawiera ona bowiem jedynie zasady ogólne, a nie zadania. Nie do zaakceptowania natomiast jest sytuacja przekazywania zadań gminom w drodze aktów podustawowych, tj. rozporządzeń. Bez względu na to, z jakich aktów prawnych zadania te będą wynikać i obciążać gminę, stanowią one zadania własne gminy.

Zadanie polegające na zaspokajaniu potrzeb mieszkaniowych wspólnoty samorządowej przez gminę ma charakter publiczny i jednocześnie lokalny (służący zaspokajaniu potrzeb mieszkańców gminy), ale nie musi mieć wyłącznie lokalnego wymiaru, tj. służyć rozwiązywaniu problemów występujących tylko w skali lokalnej. Pomimo zatem faktu, że zaspokajanie potrzeb mieszkaniowych członków wspólnoty samorządowej ma przymiot zadania publicznego (wynika bowiem z ustawy) oraz wykracza poza gminę (jest realizowane przez różne podmioty z zakresu administracji publicznej), posiada ono wymiar zadania lokalnego, ponieważ jest co do zasady realizowane przez gminę.

Należy ponadto wskazać, że problem podziału zadań pomiędzy samorząd terytorialny a administrację rządową nabiera szczególnego znaczenia wówczas, gdy ustawodawca przekazał konkretne zadanie do realizacji przez gminę (można rzec - pozbył się problemu z realizacją zadania), a po upływie, krótszego lub dłuższego, czasu administracja rządowa zaczyna realizować politykę wspierania zapewnienia potrzeb, nie poprzez przekazanie środków finansowych gminom, tylko poprzez realizację tych funkcji samorządowych, czyli prowadzi działania wykonawcze. Działanie takie prowadzić będzie do konfliktu pomiędzy szczeblami administracji publicznej, tj. szczeblem samorządowym i rządowym. Konflikt ten o tyle jest akceptowalny, że wspólnota lokalna, jak i wspólnota krajowa może na takich działaniach skorzystać. Nie zmienia to faktu, że to nie samorząd realizuje takie funkcje.

\section{Sposób realizacji zadań przez samorząd gminny}

Trybunał Konstytucyjny wskazał, że art. 4 u.n.I. poprzez bardzo ogólne sformułowanie „zaspokajanie potrzeb mieszkaniowych członków wspólnoty samorządowej” ustanowił nowe zadanie własne gminy jako jednostki samorządu terytorialnego. Zadanie to nie zawiera się w katalogu zadań samorządu terytorialnego ujętym w art. 7 u.s.t. (obecnie ustawa o samorządzie gminnym). Według Trybunału w art. 4 u.n.l. sformułowane zostało generalne zadanie własne gminy, tj. „zaspokajanie potrzeb mieszkaniowych członków wspólnoty samorządowej", wyznaczające sferę właściwości rzeczowej gminy i kierunek działań podejmowanych przez gminę. Jak zauważył TK, działania te 
muszą znajdować oparcie w przepisach prawa powszechnie obowiązującego (jeśli mają władczy charakter), a także być realizowane w ściśle określonych formach prawnych i przy wykorzystaniu posiadanych przez gminę środków.

Jednocześnie Trybunał wskazał, że realizacja powyższego generalnego zadania może następować poprzez wykonywanie innych zadań ustawowych, tzw. detalizujących lub pośrednio przyczyniających się do zaspokajania potrzeb mieszkaniowych. Do pierwszego rodzaju zadań zaliczone zostało np. budownictwo mieszkaniowe komunalne (art. 7 pkt 7 u.s.t.) oraz wypłata dodatków mieszkaniowych (art. 45 ust. 1 u.n.l.). Do drugiego rodzaju zadań TK zaliczył m.in. zapewnienie terenów przeznaczonych pod budownictwo mieszkaniowe (art. 7 pkt 1-3 u.s.t.).

Trybunał Konstytucyjny zauważył także, że art. 4 u.n.l., przyznając gminie dodatkowe zadanie własne, jakim jest „zaspokajanie potrzeb mieszkaniowych członków wspólnoty samorządowej", nie wyklucza jego realizacji przez różne podmioty. Po pierwsze, zaspokojenie potrzeb mieszkaniowych należy do samych zainteresowanych. Po drugie, może ono być realizowane przez organy administracji publicznej inne niż gmina z zastrzeżeniem, że obciążenie tym zadaniem musi być dokonane w drodze ustawowej. Po trzecie, musi ono być realizowane przede wszystkim przez gminę. Jak podkreślił TK, realizacja tego zadania nie nakłada na gminy obowiązku pełnego zaspokojenia wszystkich potrzeb mieszkaniowych mieszkańców gminy. Nie nakłada także na gminy terminu ich zaspokojenia ani też obowiązku wykorzystania wszystkich dostępnych środków. Jak się wydaje, Trybunał wykluczył wartościowanie zadań realizowanych przez gminę i realizowanie jednych kosztem drugich - w omawianym przypadku chodzi o „zaspokajanie potrzeb mieszkaniowych” i zaniedbywanie innych zadań lokalnych.

W powyższym kontekście należy postawić dwa pytania:

1. Co oznacza realizowanie zadań własnych przez gminę?

2. Czy realizację działań detalizujących można uznać ze pełną realizację zadania własnego?

Realizowanie zadań własnych przez gminę oznacza zaspokajanie potrzeb wspólnoty samorządowej stosownie do potrzeb i możliwości finansowych gminy. Bardzo często potrzeby mieszkańców będą znacznie przekraczały możliwości ich zaspokojenia, co nie oznacza, że gmina może nie realizować konkretnego zadania własnego. Gmina ma obowiązek realizacji zadania własnego nawet wówczas, gdy nie jest w stanie zabezpieczyć całości pokrycia finansowego jego realizacji. Zakres realizacji zadania musi być dostosowany do możliwości finansowych gminy, ewentualnie gmina powinna szukać innych rozwiązań, aby mogła skutecznie realizować konkretne zadanie. Warto również zauważyć, że wszystkie zadania własne gminy muszą być realizowane i nie można przyznawać priorytetu wybranym zadaniom lub realizować niektóre zadania kosztem innych zadań. Dlatego też każda gmina musi rozdzielać posiadane środki finansowe na wszystkie zadania, biorąc pod uwagę nie tylko istniejące potrzeby w ramach konkretnych zadań, ale przede wszystkim możliwości z finansowania realizacji tych zadań. 
Zadanie, jakim jest „zaspokajanie potrzeb mieszkaniowych członków wspólnoty samorządowej", może być realizowane w różny sposób. Gmina może je realizować na dwa sposoby. Po pierwsze, w sposób bezpośredni, np. budując, samodzielnie bądź przy wykorzystaniu spółek komunalnych, mieszkania komunalne czy lokale socjalne. Po drugie, może także realizować je poprzez wykonywanie innych zadań. Jak się wydaje, można wskazać tu zadania, o których wspomniał Trybunał, oraz te wskazane w ustawie o samorządzie terytorialnym. Na szczególną uwagę zasługują zadania z zakresu planowania przestrzennego, a przede wszystkim uchwalanie miejscowych planów zagospodarowania przestrzennego, w treści których nastąpi przeznaczenie terenów pod budownictwo mieszkaniowe.

Należy zauważyć, że o zaspokojeniu potrzeb mieszkaniowych - czyli o pełnej realizacji zadania, będzie można mówić wówczas, gdy realizacja zadania detalizującego lub kilku takich zadań doprowadzi do uzyskania lokalu mieszkalnego przez mieszkańca gminy, np. poprzez wypłatę dodatku mieszkaniowego osoba taka będzie posiadała zdolność do wynajęcia lokalu mieszkalnego.

Przedmiotowe zadanie może, a w ocenie piszącego niniejszą glosę musi, być realizowane przez różne podmioty, w szczególności przez samych zainteresowanych (mieszkańców gminy) oraz organy administracji publicznej, np. organy samorządu wojewódzkiego i organy administracji rządowej. Zaspokojenie wszystkich potrzeb mieszkaniowych mieszkańców przez wyżej wymienione podmioty jest zadaniem nierealnym do zrealizowania, tym bardziej przez samą gminę, mając na uwadze, że jest to jedno z najbardziej kosztownych zadań i w przypadku wielu gmin jego realizacja mogłaby doprowadzić do naruszenia równowagi budżetowej i zadłużenia gmin. Dlatego też przy jego realizacji konieczne jest współdziałanie wielu podmiotów - organów administracji publicznej szczebla powiatowego i wojewódzkiego oraz organów administracji rządowej. Możliwe jest także realizowanie tego zadania w ramach tzw. partnerstwa publiczno-prywatnego.

\section{Finansowe zabezpieczenie realizacji zadań przez samorząd gminny}

Trybunał Konstytucyjny rozpatrywał także kwestie zabezpieczenia finansowego na realizację przekazanych gminie zadań. Uczynił to na kanwie zgodności przepisu art. 45 ust. 2 u.n.l. $z$ art. 73 ust. 2 Małej Konstytucji. Zakwestionowany przepis ustawowy zapewnia bowiem gminom otrzymywanie dotacji celowych z budżetu państwa w granicach kwot określonych na ten cel w ustawie budżetowej - na dofinansowanie środków przeznaczonych na wypłatę dodatków mieszkaniowych. Oznacza to, według Trybunału, że dotacje celowe już w samym założeniu ustawodawcy nie mają zapewnić pełnego pokrycia wydatków ponoszonych przez gminy w związku z nałożonym na nie nowym „zadaniem własnym", polegającym na wypłacaniu osobom uprawnionym dodatków mieszkaniowych. 
Trybunał Konstytucyjny wskazał, że ustawodawca, obciążając gminy nowym zadaniem własnym, polegającym na wypłacaniu dodatków mieszkaniowych i nie zapewniając równocześnie pełnego pokrycia związanych z tym zadaniem wydatków ze środków odpowiedniej dotacji celowej, nie naruszył zasad i przepisów Małej Konstytucji z dwóch przesłanek:

1. zadania własne gmin co do zasady finansowane są z własnych źródeł (dochodów);

2. realizacja zadań własnych gminy może być wspierana z budżetu państwa, m.in. w formie dotacji celowej.

Jak podkreślił TK, ustawodawca, obarczając gminy nowym zadaniem własnym, jednocześnie „stworzył możliwość” zwiększenia dochodów gminy przez podwyższenie czynszu tzw. regulowanego za lokale mieszkalne w budynkach stanowiących mieszkaniowy zasób gminy (art. 25 i art. 26 u.n.l.). Dochody z czynszu miały służyć pokryciu wydatków związanych z wypłatą dodatków mieszkaniowych, a dotacja celowa ma stanowić tylko uzupełnienie - jak zapisano w art. 45 ust. 2 u.n.l. - dofinansowania zadania, w żadnym wypadku nie może być zaś traktowana jako jedyne źródło jego finansowania. Dodatkowo, jak wskazał Trybunał, wysokość dotacji jest skorelowana z wysokością kwoty uzyskanej przez konkretną gminę w wyniku podwyższenia czynszów regulowanych.

Jednocześnie Trybunał Konstytucyjny wskazał, że przekazując gminom nowe zadanie do realizacji, niezbędne jest:

1. zagwarantowanie w projekcie ustawy budżetowej kwot odpowiadających potrzebom gmin związanych z wypłatą dodatków mieszkaniowych - podmiotem zobowiązanym jest Rada Ministrów;

2. uchwalenie wyżej wymienionej ustawy budżetowej, która gwarantuje pełne dofinansowanie z budżetu państwa wydatków ponoszonych przez gminy na cele wypłaty dodatków mieszkaniowych - podmiotem zobowiązanym jest ustawodawca (Sejm).

„Pełne dofinansowanie”, o którym wspomina Trybunał, obejmuje całkowite pokrycie tej części wydatków na dodatki mieszkaniowe, która zgodnie z postanowieniami ustawy lub ustaw ma być pokryta - w drodze dofinansowania - z budżetu państwa.

Ustawowa konstrukcja pokrywania kosztów wypłaty dodatków mieszkaniowych odpowiada - zdaniem Trybunału Konstytucyjnego - konstytucyjnym zasadom ustroju samorządu terytorialnego, wyrażonym w szczególności w powołanych przez wnioskodawców art. 71 ust. 2 oraz art. 73 ust. 2 Małej Konstytucji, ponieważ ani nie koliduje z samodzielnością samorządu terytorialnego, ani też nie narusza wymogu ustawowego gwarantowania źródeł dochodów jednostek samorządu terytorialnego w zakresie zadań publicznych.

Z wyżej wymienionego wyroku Trybunału Konstytucyjnego jednoznacznie wynika, że wysokość środków finansowych na zabezpieczenie wypłaty gminom dotacji celowej powinna być ustalona w akcie rangi ustawowej. Ponadto ustawowo powinien być określony tryb wypłacania dodatków (np. termin, do którego powinny być przekazane środki z budżetu państwa), tak aby zapewnić prawidłową realizację zadań gminy. Inne elementy związane z przekazywaniem poszczególnym gminom z budżetu państwa 
dotacji mogą natomiast wynikać z rozporządzenia, przy czym upoważnienie ustawowe do jego wydania nie może być blankietowe (ogólne) - musi ono chociażby wskazywać kierunki rozstrzygnięć, jakie rozporządzenie miałoby zawierać.

W swoim rozstrzygnięciu Trybunał podniósł także kwestię wejścia w życie ustawy w trakcie roku budżetowego. W ocenie TK jest to dopuszczalne pod warunkiem zapewnienia w ustawie budżetowej środków finansowych wystarczających na pokrycie potrzeb gmin związanych z nowym zadaniem.

Warto w tym miejscu odnieść się do postanowień EKST. Pomijając kwestię wejścia w życie Karty oraz ustawy o najmie lokali, należy wskazać na postanowienia Karty, które mają istotne znaczenie dla omawianego wyżej zagadnienia. Trybunał przyjął a priori, że kwestionowana ustawa, a szerzej rzecz ujmując, wszystkie akty prawa, uchwalone przed ratyfikacją EKST są zgodne z jej postanowieniami. Jednocześnie TK wskazał na art. 9 ust. 2 Karty, który stanowi, że: „Wysokość zasobów finansowych społeczności lokalnych powinna być dostosowana do zakresu uprawnień przyznanych im przez Konstytucję lub przez prawo". Z powyższego zapisu, zdaniem Trybunału, nie wynika obowiązek państwa do zapewnienia założonej w tych postanowieniach adekwatności zasobów finansowych do zadań tylko przy pomocy subwencji, lecz przez określony mechanizm prawny pozyskiwania przez samorząd terytorialny środków finansowych ze wszystkich źródeł. Mechanizm taki, według Trybunału, został ustanowiony.

Powyższe poglądy Trybunału Konstytucyjnego zasługują na akceptację w części dotyczącej zasady ponoszenia kosztów związanych z realizacją zadań własnych przez gminę, tj. finansowania ich realizacji, m.in. ze środków własnych gminy.

Trudno jest zaakceptować stanowisko Trybunału wyrażone w niniejszym orzeczeniu dotyczące zdefiniowania „pełnego dofinansowania”, które, jak się wydaje, rozumiane jest przez TK jako pokrycie tylko części wydatków związanych z realizacją nowego zadania przekazanego gminie do realizacji, tj. wypłatą dodatków mieszkaniowych. O takim rozumieniu świadczy przede wszystkim stwierdzenie TK, że dotacje celowe z założenia nie zapewniają pełnego pokrycia wydatków ponoszonych przez gminy realizujące nowe „zadanie własne", polegające na wypłacaniu osobom uprawnionym dodatków mieszkaniowych, a także pozostawienie ustawodawcy możliwości swobodnego ustalenia tego w aktach rangi ustawowej (Trybunał użył sformułowania: „zgodnie z postanowieniami ustawy lub ustaw"). Swoboda ta, jak się wydaje, prowadzić będzie do ograniczania zasobów finansowych przekazywanych z budżetu państwa podmiotom, które zobowiązane zostaną do realizacji nowego zadania nawet wówczas, gdy będzie ono zadaniem własnym tego podmiotu. Ograniczeniu ulegną także posiadane zasoby finansowe na realizację innych zadań, ponieważ gmina, przy ograniczonych środkach z budżetu na to konkretne zadanie, będzie musiała finansować jego realizację z własnych dochodów.

Przy finansowaniu działalności jednostek samorządu terytorialnego, zarówno pod rządami Małej Konstytucji, jak i obecnie obowiązującej Konstytucji RP, jak się wydaje, zastosowanie ma zasada adekwatności, a także zasada samodzielności finansowej.

8 Zob. wyrok TK z dnia 24 marca 1998 r., K 40/97, OTK ZU 1998, nr 2, poz. 12. 
Zasada adekwatności nakłada na ustawodawcę obowiązek zagwarantowania odpowiednich środków do przekazywanych zadań. A zatem konieczne jest zachowanie równowagi pomiędzy poziomem finansowania a zakresem zadań realizowanych przez j.s.t. Aby samorząd terytorialny spełniał swoje funkcje, wymaga odpowiednich do tego nakładów finansowych. Zasada ta nie oznacza jednakże nakazu każdorazowego zwiększania środków finansowych wraz z przekazywaniem j.s.t. nowych zadań. Środki te powinny być jedynie adekwatne, co oznacza, że nowe zadanie nałożone na samorząd może być finansowane z zachowaniem poziomu finansowania danej jednostki z zastrzeżeniem każdorazowej indywidualnej oceny, ze względu na trudności z prostym przeliczeniem, czy też wyliczeniem zadań i ich ewentualnych kosztów ${ }^{9}$. Ustawodawca nie może zatem przyznawać j.s.t. środków finansowych na poziomie uniemożliwiającym wykonanie powierzonych im zadań ${ }^{10}$.

Zasada samodzielności finansowej wynika z zasady samodzielności samorządu terytorialnego ${ }^{11}$ i stanowi jedną z konstytutywnych jego cech. Jej istota wyraża się w zapewnieniu jednostkom samorządu terytorialnego dochodów pozwalających na realizowanie przypisanych im zadań publicznych, pozostawiając tym jednostkom, przy uwzględnieniu wymogów ustawowych, swobodę kształtowania wydatków. Trzeba podkreślić, że samodzielność finansowa wymaga od ustawodawcy przepisów, dających gwarancje formalne i proceduralne jej zachowania ${ }^{12}$.

Przyznana gminom samodzielność nie jest bezwzględna i może podlegać ograniczeniu. Dotyczy to także samodzielności finansowej, która może podlegać modyfikacjom przez ustawodawcę w zakresie wysokości dochodów, ich źródeł, jak również ewentualnych obowiązków z nich wynikających ${ }^{13}$. Zmiany w zakresie zadań i kompetencji jednostek samorządu terytorialnego mogą nastąpić tylko wraz z odpowiednimi zmianami w podziale dochodów publicznych. Ustawodawca, wprowadzając regulacje nakładające na j.s.t. poszczególne zadania, musi zapewnić tym jednostkom odpowiednie dochody. Konsekwencją tego jest więc zakaz podejmowania takich działań, które

9 Zob. wyrok TK z dnia 25 lipca 2006 r., K 30/04, IPO TK [dostęp: 13.12.2019].

${ }^{10}$ Zob. wyrok TK z dnia 31 stycznia 2013 r., K 14/11, OTK ZU 2013, nr 1A, poz. 7.

11 Zob. wyrok TK z dnia 12 marca 2007 r., K 54/05, OTK ZU 2007, nr 3A, poz. 25, w którym Trybunał Konstytucyjny podsumował dotychczasowe rozważania i wskazał znaczenie zasady samodzielności. Zasada ta oznacza w szczególności, że: „1) jednostki samorządu terytorialnego mają określony zakres zadań własnych związanych z zaspokajaniem potrzeb mieszkańców oraz zadań zleconych określonych przez ustawy; 2) jednostki samorządu terytorialnego samodzielnie realizują swoje zadania, wyrażając wolę mieszkańców; 3) ingerencja organów władzy wykonawczej w realizację tych zadań powinna zostać ograniczona do procedur nadzorczych opartych na kryterium legalności; jest ona dopuszczalna tylko w wypadkach określonych w ustawach; 4) ingerencja prawodawcza w sferę samodzielności samorządu terytorialnego wymaga zachowania formy ustawowej oraz poszanowania zasady zupełności regulacji ustawowych; 5) wszelka ingerencja w sferę samodzielności jednostek samorządu terytorialnego musi być zgodna z zasadą proporcjonalności; 6) prawa i interesy jednostek samorządu terytorialnego podlegają ochronie sądowej".

12 Zob. wyrok TK z dnia 24 marca 1998 r., K 40/97, OTK ZU 1998, nr 2, poz. 12.

${ }^{13}$ Zob. wyrok TK z dnia 25 lipca 2006 r., K 30/04, IPO TK [dostęp: 13.12.2019]. 
zmieniałyby strukturę dochodów, a dalej - przekreślałyby realizację zadań powierzonych jednostkom samorządu terytorialnego ${ }^{14}$.

Nakładanie zadań na gminy wiąże się zatem z obowiązkiem ustawodawcy do zagwarantowania środków finansowych w wysokości wystarczającej na ich realizację rozumianego jako zabezpieczenie w budżecie państwa środków finansowych umożliwiających pokrycie realizacji tych zadań, co najmniej, na dotychczasowym poziomie.

Trzeba podkreślić, że w omawianym przypadku mamy do czynienia ze stałym, powtarzalnym i niedającym się samodzielnie ukształtować - jeśli chodzi o sposób wykonywania - zadaniem, nazwanym w dodatku przez ustawodawcę „zadaniem własnym”. Niedopuszczalne jest zatem gwarantowanie gminie jej dochodów własnych jedynie poprzez "stworzenie możliwości” zwiększenia dochodów lokalnych (w omawianym przypadku - przez podwyższenie czynszu regulowanego za lokale mieszkalne w budynkach stanowiących mieszkaniowy zasób gminy), a nie faktyczne ich zabezpieczenie. Każda gmina dysponuje bowiem innym zasobem mieszkaniowym i chociażby ze względu na położenie poszczególnych gmin (obszary wiejskie, miejskie) i wielkość tego zasobu, a co się z tym ściśle wiąże, na zróżnicowanie wysokości już pobieranego czynszu może się okazać, że jego podwyższenie skutkować będzie obniżeniem wpływów do budżetu gminy, a nie jego wzrostem ${ }^{15}$.

Prowadzi to do konstatacji, że przyjęte przez ustawodawcę rozwiązanie ustawowe gwarantujące gminie dodatkowe dochody własne, w bliżej nieokreślonej wysokości i czasie, nie może być zaakceptowane.

\section{Literatura}

Agopszowicz A., Glosa do orzeczenia TK z dnia 23 października 1995 r., K 4/95, „Samorząd Terytorialny" 1996, nr 7-8.

Borodo A., Glosa do orzeczenia TK z dnia 23 października 1995 r., K 4/95, „Samorząd Terytorialny” $1996, \mathrm{nr} 10$.

Gajl N., Glosa do orzeczenia TK z dnia 23 października 1995 r., K 4/95, „Samorząd Terytorialny” 1996, nr 10.

Kornberger-Sokołowska E., Realizacja zasady adekwatności w procesach decentralizacji finansów, „Samorząd Terytorialny" 2001, nr 3.

Podgórski K., Nitecki S., Glosa do orzeczenia TK z dnia 23 października 1995 r., K 4/95, „Samorząd Terytorialny" 1996, nr 10.

Tegler E., Glosa do orzeczenia TK z dnia 23 października 1995 r., K 4/95, "Samorząd Terytorialny” 1996, nr 7-8.

\footnotetext{
14 Zob. ibidem.

15 Zob. wyrok TK z dnia 8 kwietnia 2010 r., P 1/08, OTK ZU 2010, nr 4A, poz. 33, w którym Trybunał Konstytucyjny wskazał na obowiązek ustawodawcy umożliwienia j.s.t. pobierania ustawowo przewidzianych dochodów i ich wydatkowania na realizowane zadania.
} 


\section{Streszczenie}

\section{Paweł Sosnowski}

\section{Ograniczenia ustawodawcy w kształtowaniu zadań gminy}

Trzydziestolecie przywrócenia w Polsce samorządu terytorialnego skłania do analiz i ocen funkcjonowania samorządu oraz formułowania kierunków jego przekształceń. To także dobry moment do przyjrzenia się orzecznictwu Trybunału Konstytucyjnego mającemu wpływ na kształt zadań i sposób ich realizacji przez wspólnoty samorządowe. Jedno z najistotniejszych orzeczeń Trybunał wydał w dniu 23 października 1995 r. (K 4/95).

Tezy postawione przez Trybunał w wyżej wymienionym orzeczeniu pomimo zmiany Konstytucji RP i ustaw - zostały bowiem sformułowane w czasie obowiązywania ustawy konstytucyjnej z dnia 17 października 1992 r. o wzajemnych stosunkach między władzą ustawodawczą i wykonawczą RP oraz o samorządzie terytorialnym, a także ustawy o najmie lokali mieszkalnych i dodatkach mieszkaniowych - nie straciły na aktualności. Można wskazać chociażby kwestie związane z określeniem charakteru zadań publicznych oraz obowiązku i ciągłości realizacji przez gminę zadań związanych z zabezpieczeniem potrzeb mieszkaniowych mieszkańców wspólnoty samorządowej.

Trybunał Konstytucyjny w przedmiotowym orzeczeniu sformułował także trzy istotne, choć dyskusyjne tezy dotyczące samorządu gminnego, a odnoszące się do: 1) pełnej swobody ustawodawcy w przekazywaniu zadań samorządowi gminnemu; 2) sposobu realizacji zadań własnych przez samorząd terytorialny, tj. poprzez realizację zadań detalizujących; 3) braku konieczności zapewnienia pełnego finansowania realizacji zadań przekazanych gminie. Powyższe tezy są przedmiotem rozważań w niniejszej glosie.

\section{Summary}

\section{Paweł Sosnowski}

\section{Limitations of the legislator in shaping the municipality's tasks}

The thirtieth anniversary of the restoration of local self-government in Poland prompts analyses and evaluations of the functioning of local self-government and the formulation of directions for its transformation. It is also a good time to take a look at the jurisprudence of the Constitutional Tribunal which have an impact on the shape of tasks and the way they are implemented by local self-government communities. One of the most important rulings in this regard was issued by the Constitutional Tribunal on 23 October 1995 (K 4/95).

The theses of the Constitutional Tribunal presented in the abovementioned decision, despite the adoption of the new Constitution of the Republic of Poland and other laws - they were formulated when the Constitutional Act of 17 October 1992 on mutual relations between the legislative and executive powers of the Republic of Poland and local self- government as well as the Act on the lease of flats and housing allowance were still in force - are still valid. These theses concerned, among others, issues related to determining the nature of public tasks as well as the obligation and continuity of the implementation of the municipality's tasks related to securing the housing needs of the members of self-government community. 
In the abovementioned judgement, the Constitutional Tribunal also formulated three important, although disputable, theses concerning the municipal self-government which referred to: 1) the full freedom of the legislator in delegating tasks to the municipal self-government; 2) the manner in which the local self-government carried out its own tasks, i.e. through the implementation of detailing tasks; 3 ) the absence of the need to ensure full financing for the implementation of tasks delegated to the municipality. The above theses are considered in the commentary.

Słowa kluczowe: przekazywanie zadań samorządowi terytorialnemu, zadania własne gminy, sposób realizacji zadań przez gminę, finansowanie zadań gminy

Keywords: delegating tasks to the local government, own tasks of the municipality, way of performing tasks by the municipality, financing of the municipality's tasks 